\title{
Unir para além da fronteira: Um esboço da etnopolítica transnacional ashaninka
}

To unite beyond borders. An outline of Ashaninka transnational ethnopolitics

José Pimenta

\section{OpenEdition}

12 Journals

Edição electrónica

URL: http://journals.openedition.org/aa/3237

DOI: 10.4000/aa.3237

ISSN: 2357-738X

Editora

Programa de Pós-Graduação em Antropologia Social (UnB)

\section{Edição impressa}

Data de publição: 1 dezembro 2018

Paginação: 173-204

ISSN: 0102-4302

\section{Refêrencia eletrónica}

José Pimenta, «Unir para além da fronteira: Um esboço da etnopolítica transnacional ashaninka», Anuário Antropológico [Online], v.43 n.2 | 2018, posto online no dia 26 maio 2019, consultado o 28 abril 2021. URL: http://journals.openedition.org/aa/3237 ; DOI: https://doi.org/10.4000/aa.3237

\section{(c) (i) (9)}

Anuário Antropológico is licensed under a Creative Commons Atribuição-Uso Não-Comercial-Proibição de realização de Obras Derivadas 4.0 International. 


\section{Unir para além da fronteira: Um esboço da etnopolítica transnacional ashaninka}

José Pimenta

UnB

\section{Introdução}

Com uma presença notável na região da Selva Central peruana e uma pequena diáspora em território brasileiro, os Ashaninka são hoje um dos povos indígenas mais numerosos da bacia Amazônia, com mais de cem mil pessoas. Como outros povos indígenas da América Latina e da Amazônia, em particular, foram separados pela formação das fronteiras dos Estados nacionais. No início do século XX, com a incorporação do Acre ao território brasileiro e a demarcação da fronteira internacional entre Brasil e Peru na região do Alto Juruá, acabaram divididos de modo extremamente desigual pela geopolítica ocidental. Hoje, menos de $2 \%$ da população ashaninka habita o território brasileiro. Esta pequena diáspora não soma duas mil pessoas divididas em sete terras indígenas, todas situadas no Acre, nos afluentes do alto rio Juruá, na fronteira com o Peru.

Entre os Ashaninka que vivem hoje no Brasil, destacam-se os da Terra Indígena Kampa do Rio Amônia, território demarcado oficialmente pela FUNAI em 1992. Com uma população atual de cerca de 800 pessoas, reagrupadas na aldeia Apiwtxa e nos seus arredores, os Ashaninka do Rio Amônia representam quase a metade das famílias situadas no Brasil. Embora extremamente minoritários se comparados à população total desse povo indígena, os Ashaninka do Amônia adquiriram uma visibilidade importante nos últimos anos em razão, principalmente, de sua atuação na política interétnica e de suas iniciativas em prol do desenvolvimento sustentável do Alto Juruá.

Num contexto marcado por divergências e conflitos em torno das políticas de desenvolvimento para essa região de fronteira, este artigo discute as relações dos Ashaninka do Rio Amônia com seus semelhantes situados em território peruano. Ele dá continuidade a uma reflexão anterior (Pimenta, 2012a) e procura desvendar algumas características recentes da etnopolítica da APIWTXA, associação dos Ashaninka do Rio Amônia. Nas páginas que se seguem, busco mostrar que a lógica colonial dos Estados-nações e a demarcação da fronteira internacional no Alto Juruá nunca apagou o sentimento étnico do povo Ashaninka, que continua se pensando 
como um povo único e diferenciado, apesar da existência de marcadores nacionais que também podem ser acionados em certos contextos. Embora sempre tenham existido laços transfronteiriços entre os Ashaninka do Brasil e do Peru, nos últimos anos, essas relações vêm adquirindo novas configurações e uma dimensão fortemente política, até então inexistente. A APIWTXA tem sido a principal promotora e articuladora dessas mudanças. Após mostrar como a fronteira entre Brasil e Peru no Alto Juruá foi imposta pela geopolítica dos brancos, separando arbitrariamente os Ashaninka, procuro refletir sobre o sentimento que une esse povo indígena e suas alianças transnacionais. Estimuladas, principalmente, por preocupações decorrentes de iniciativas desenvolvimentistas dos Estados-nações, como também por atividades ilegais que ameaçam seus territórios e direitos, essas alianças intraétnicas unem os Ashaninka dos dois países sem diluir suas especificidades nacionais. Também se traduzem por concepções próprias e dinâmicas em relação à fronteira internacional. ${ }^{1}$

A “chegada do Brasil” e a demarcação da Terra Indígena Kampa do Rio Amônia: a fronteira como limite

Para a historiografia ocidental, a região acreana do Alto Juruá, disputada pelo Brasil, Bolívia e Peru, nasceu com a epopeia da borracha e a chegada dos seringueiros a partir das últimas décadas do século XIX. Não cabe descrever aqui os pormenores que levaram essa região a se tornar brasileira no início do século XX. Uma das características mais marcantes da "invenção do Acre" (Carneiro, 2014) é o lugar marginal que a história oficial sempre atribuiu aos povos indígenas (Pimenta, 2015). Para a história ocidental, antes da economia da borracha, o Acre e o Alto Juruá praticamente não existem. O título do livro de Craveiro Costa, "A conquista do deserto ocidental" (1998), ilustra perfeitamente essa ideia.

Assinado no dia 17 de novembro de 1903 pelo Brasil e pela Bolívia, o Tratado de Petrópolis revisou os limites do Tratado de Ayacucho, de 1867, e é considerado a certidão de nascimento do então Território Federal do Acre (hoje Estado do Acre) como terra brasileira dividida em três departamentos: Alto Acre, Alto Purus e Alto Juruá. No entanto, esse tratado não resolveu o litígio fronteiriço entre Brasil e Peru nem no Alto Purus, nem no Alto Juruá. Em novembro de 1904, por exemplo, um conflito armado opôs seringueiros brasileiros e caucheiros peruanos pelo controle da produção de borracha do então seringal Minas Gerais, situado na foz do Rio Amônia, na confluência com o rio Juruá. Conhecido na literatura como "Guerra da Trincheira” ou "Batalha do Amônia” (Tocantins, 1979: 396-405), esse conflito resul- 
tou na vitória dos seringueiros brasileiros. Com o levante, o pequeno povoado de Nueva Iquitos, onde os peruanos tinham instalado um posto aduaneiro para recolher impostos sobre a produção de borracha, passou para o controle brasileiro, sendo renomeado, em homenagem ao líder da revolta, o militar e político Gregório Thaumaturgo de Azevedo, como Distrito Thaumaturgo, posteriormente, Vila Thaumaturgo e, desde 1992, município Marechal Thaumaturgo.

A vitória brasileira não acabou com as pretensões peruanas na região e a questão fronteiriça entre o Brasil e o Peru se arrastou por mais alguns anos. Nomeados pelo Barão do Rio Branco, o coronel Belarmino Mendonça chefiou a Comissão Brasileira de Reconhecimento do Rio Juruá, em 1905 (Mendonça, 1989), enquanto Euclides da Cunha liderou trabalho semelhante no rio Purus. A disputa entre Brasil e Peru pela demarcação da fronteira internacional, tanto no Alto Juruá como no Alto Purus, só foi oficialmente encerrada via diplomacia, em 08 de setembro de 1909, com a assinatura do Tratado do Rio de Janeiro.

A “questão indígena” foi um detalhe na conquista do Alto Juruá e na integração do Acre ao Brasil. Embora nunca tenha considerado os índios como atores, a historiografia do Acre não pôde ocultar totalmente sua presença na virada do século XIX para o XX. Assim, no auge da economia da borracha, ou seja, entre 1890 e 1912, quando o Alto Juruá era disputado por seringueiros brasileiros e caucheiros peruanos, encontramos na literatura referências à presença de diferentes povos indígenas, principalmente da família linguística Pano, como os Kaxinawá (Huni Kuin) e os Amahuaca, mas também os Ashaninka da família Arawak.

Historiadores e antropólogos datam, geralmente, a presença dos Ashaninka no Alto Juruá do final do século XIX a início do século XX. O padre francês Jean-Baptiste Perrissier, em viagem apostólica à região, em 1897 e 1898, foi o primeiro ocidental a documentar a presença desse povo indígena na boca do Rio Amônia; índios que ele apresenta, equivocadamente, como "os antigos Incas do Peru” (Perrissier, [1898] 2009: 56).

Na historiografia da região, os Ashaninka são geralmente descritos como originários do Peru, trazidos para o Brasil por patrões caucheiros peruanos a partir do final do século XIX. Embora não haja dúvidas que a pressão da exploração do caucho tenha contribuído para a migração de famílias ashaninkas para a região do Alto Juruá, outras hipóteses, que independem dos brancos, também precisam ser consideradas. O registro de Perrissier e as narrativas dos Ashaninka do Amônia nos convidam a um olhar menos etnocêntrico e a uma maior modéstia na nossa abor- 
dagem da história local.

A história ashaninka no Alto Juruá é extremamente difícil de mapear. Caracteriza-se por uma intensa mobilidade que torna extremamente complexo o traçar dos múltiplos deslocamentos desse povo indígena nessa região de fronteira. No entanto, essa mobilidade não deve ser considerada somente como decorrente de imperativos ecológicos ou da pressão dos brancos sobre seu território. Trata-se, também, de uma característica estrutural da sociedade ashaninka. Ela expressa, por exemplo, valores fundamentais, como o ideal de liberdade, uma aspiração constante na história desse povo indígena. De modo geral, os deslocamentos ashaninkas podem ser motivados por vários fatores: agrupamento familiar, escassez de recursos naturais de um determinado ecossistema, trocas e comércio, alianças políticas, disputas internas, morte de parentes, busca por um "bom patrão", pressão dos brancos ou, simplesmente, pelo gosto de viajar e conhecer novos lugares.

Apesar da impossibilidade de mapear essa mobilidade, a presença ashaninka na região do Alto Juruá, em terras que se tornaram brasileiras no final da primeira década do século XX, data, no mínimo, do final do século XIX, portanto, antes da demarcação da fronteira internacional. Essa presença foi documentada por Perissier em 1898, mas também é atestada pela história oral ashaninka, transmitida de geração a geração, na qual encontramos referências, por exemplo, à "Batalha do Amônia" de novembro de 1904.

Assim, a versão consagrada pela historiografia, e comumente aceita, que apresenta os Ashaninka como um povo indígena peruano que migrou para o Brasil no final do século XIX, é, em primeiro lugar, um anacronismo histórico, já que os limites entre o Brasil e o Peru sequer haviam sido definidos naquela época. Em segundo lugar, é um equívoco que pode ocasionar interpretações políticas perversas. Ainda hoje, é comum ouvir que os Ashaninka são "descendentes dos Incas", como afirmava Perrissier há mais de um século, ou, simplesmente, "índios peruanos"; alegações que, por vezes, visam questionar a legitimidade de seus direitos constitucionais em solo brasileiro. Mesmo se o argumento do pioneirismo e da anterioridade da ocupação territorial não tem nenhum respaldo jurídico para a garantia dos direitos territoriais indígenas, as lideranças dos Ashaninka do Rio Amônia, quando acusadas de ser "índios peruanos" ou "índios que vieram do Peru", fazem questão de lembrar que não foram eles que vieram para o Brasil, mas que foi o Brasil que incorporou um território que eles já habitavam.

No Alto Juruá, durante o auge da economia gomífera, os Ashaninka, aprecia- 
dos por suas qualidades no comércio e sua fama guerreira, serviram aos desejos dos patrões brancos, ao mesmo tempo em que satisfaziam seus próprios interesses. Contrariamente a muitos índios da região que passaram, progressivamente, a trabalhar como seringueiros no regime semi-escravagista do aviamento, os Ashaninka, com algumas exceções, nunca atuaram como mão de obra servil na exploração da borracha. Algumas famílias instalaram-se estrategicamente no curso médio do Rio Amônia, próximos à fronteira com o Peru, numa área com baixa densidade de seringueiras e, portanto, livre da ganância dos brancos. De lá, estabeleceram relações comerciais intermitentes com os regionais, trocando produtos da floresta (madeira, peles de animais silvestres, caucho, carne de caça, etc.) por bens industriais. Atuaram também como "guardiões dos seringais", encarregados de eliminar os índios "brabos" da região. Durante a maior parte do século XX, os Ashaninka do Rio Amônia procuram manter seu modo de vida e esses contatos esporádicos com os brancos regionais. Viveram durante décadas em relativa tranquilidade, até a invasão de seu território, cobiçado por sua madeira de lei, principalmente, cedro e mogno.

Na década de 1980, a exploração intensiva de madeira tornou-se a principal atividade econômica desse afluente do rio Juruá que, nesse período, ganhou o apelido de "rio da madeira". A atividade madeireira teve consequências desastrosas para o meio ambiente e afetou profundamente a organização social e a vida cultural dos Ashaninka. Diante dessa situação de crise aguda, as famílias indígenas do Rio Amônia se uniram em torno do grupo familiar de Antônio Piyãko para reivindicar do Estado a demarcação de seu território. Criaram uma aldeia ou comunidade à qual deram o nome Apiwtxa, que significa "todos juntos" e simboliza a união desse grupo. Em 1992, alcançaram seu principal objetivo com a demarcação da Terra Indígena Kampa do Rio Amônia. Com uma área de 87 mil hectares, a terra faz limite com a Reserva Extrativista do Alto Juruá, a Terra Indígena Arara do Rio Amônia e o Parque Nacional da Serra do Divisor em território brasileiro; em seu limite sul e oeste, faz fronteira com o Peru. No ano seguinte à demarcação, preocupados em encontrar alternativas econômicas à exploração predatória de madeira, criaram uma associação, que também nomearam APIWTXA, ${ }^{2}$ e buscaram parcerias para implementar projetos de desenvolvimento sustentável na terra indígena.

A demarcação da Terra Indígena Kampa do Rio Amônia levou, paulatinamente, a uma nova concepção do território e da fronteira internacional. Os Ashaninka nunca deixaram de circular livremente entre Brasil e Peru no Alto Juruá. Conhecem perfeitamente as rotas fluviais e os varadouros que ligam os dois países e atravessam 
a fronteira, principalmente na época do verão, para visitar familiares, amigos ou, simplesmente, como dizem, "para passear”. Se a fronteira é permeável, não significa, entretanto, que não tenha uma realidade concreta ou que seja insignificante. Embora persistam, os deslocamentos e migrações transfronteiriços tornaram-se menos frequentes entre os Ashaninka do Rio Amônia após a demarcação de sua terra. A principal razão dessa redução está numa nova concepção de território que se construiu, pouco a pouco, nas últimas duas décadas.

Embora saibam da importância política de ter um território demarcado pelo qual tanto lutaram, não é raro que alguns índios do Rio Amônia comparem sua atual situação ao confinamento de uma prisão na qual estariam reclusos, sem a liberdade de ir e vir. Essa analogia pode parecer exagerada, mas revela uma clara consciência, socialmente compartilhada, de viver hoje numa terra com limites claramente definidos. Como parte da terra indígena também faz divisa com o Peru, a noção de "fronteira", imposta pela geopolítica dos brancos, tornou-se, aos poucos, uma realidade concreta e palpável.

A consciência de viver num território com limites claros começou a se cristalizar com o processo de demarcação do qual homens ashaninkas da Apiwtxa participaram ativamente, abrindo picadas na mata para delimitar a área. Essa consciência se desenvolveu nos anos seguintes e se fortaleceu com o projeto de etnomapeamento em meados dos anos 2000, do qual tive a oportunidade de participar como consultor (Gavazzi, 2012). Embora a ideia de que seu território real, a despeito do imaginado e mítico, era claramente delimitado já estivesse clara, por exemplo, nas práticas cotidianas de caça, pesca e coleta, durante o etnomapeamento, pela primeira vez, muitos ashaninkas lidaram com mapas concretos de sua terra.

A consciência de viver num território com limites resulta de várias experiências, mas foi alimentada, sobretudo, pela necessidade de enfrentar invasões periódicas ao seu território. Apesar de demarcada oficialmente, a Terra Indígena Kampa do Rio Amônia continuou sendo invadida por brancos vizinhos que, diante do esgotamento dos recursos naturais em seus próprios territórios e por falta de alternativas econômicas, entraram ilegalmente na terra indígena em busca de caça ou madeira. Essas invasões levaram os Ashaninka a uma preocupação constante com os limites de sua terra, cuja inviolabilidade procuram assegurar.

Diante dessas invasões, as lideranças da APIWTXA perceberam muito cedo que qualquer política que não considerasse também os problemas do entorno de seu território levaria inevitavelmente ao fracasso. Por isso, sempre procuraram ampliar 
e difundir suas experiências com os projetos de desenvolvimento sustentável para conscientizar seus vizinhos, indígenas ou não, e implementar progressivamente um vasto plano de gestão ambiental de toda a bacia do Alto Juruá. Essa preocupação em envolver as comunidades do entorno em suas atividades tornou-se uma marca da etnopolítica da associação APIWTXA, que procura sensibilizar a população da região com os ideais do desenvolvimento sustentável. Ao buscar parcerias e integrar outros povos indígenas e famílias não indígenas da região nos projetos por eles desenvolvidos, cultivam a esperança de que essas famílias atuem como transmissores e multiplicadores de uma nova consciência ambiental e encontrem alternativas econômicas às políticas tradicionais de desenvolvimento, baseadas na exploração predatória de madeira e na pecuária (Pimenta, 2010).

Os Ashaninka do Rio Amônia não se limitaram ao estabelecimento de alianças interétnicas com a população indígena e não indígena do Alto Juruá brasileiro. Invasões e ameaças à Terra Indígena Kampa do Rio Amônia também ocorrem na sua divisa com o Peru. Como veremos adiante, ao longo da fronteira internacional, a atuação de madeireiros, mas também de narcotraficantes, coloca em risco a integridade do território dos Ashaninka do Rio Amônia. As ameaças vindas do país vizinho e as políticas desenvolvimentistas do governo peruano fizeram da fronteira internacional, que margeia parte da Terra Indígena Kampa do Rio Amônia, um problema extremamente sensível, capaz de pôr em risco todas as ações dessa comunidade em prol da sustentabilidade de seu território. Diante deste cenário, a APIWTXA, além das alianças construídas com os brancos e outros índios do Alto Juruá brasileiro, procurou expandir sua agenda política para o país vizinho, buscando parcerias com comunidades e associações indígenas peruanas, principalmente, com seus parentes ashaninkas, considerados peças-chave nesse processo de união transfronteiriça em prol do desenvolvimento sustentável. A APIWTXA tem sido a principal protagonista na construção dessas alianças intraétnicas transnacionais que ocorrem num contexto marcado por políticas desenvolvimentistas em curso na Amazônia peruana e que ameaçam diretamente os direitos indígenas e os territórios protegidos nessa região de fronteira. Antes de proceder à análise dessas alianças e explicitar seu contexto, é importante esclarecer o sentimento que une o povo Ashaninka para além da fronteira internacional.

\section{Um povo único: a fronteira invisível}

Os Ashaninka são o principal componente do conjunto etnolinguístico dos 
Arawak subandinos. Existem ainda muitas controvérsias entre antropólogos e linguistas para delimitar as fronteiras étnicas e sociais dessa família etnolinguística e de seus componentes. Geralmente, entende-se por Arawak subandinos ou pré-andinos, o conjunto composto pelos: Ashaninka, Asheninka, Nomatsiguenga, Matsiguenga, Yanesha e Yine, sendo que a inserção destes dois últimos povos no conjunto é ainda mais problemática em razão de afinidades com povos Pano vizinhos. Não cabe aqui explorar os pormenores das classificações etnolinguísticas que variam sensivelmente em função dos autores, dos contextos de análises, da maleabilidade das fronteiras étnicas e das dinâmicas identitárias. ${ }^{3}$ No entanto, é importante frisar que uso o termo Ashaninka de forma genérica e inclusiva para me referir tanto aos Ashaninka, como aos Asheninka. Como mostrarei adiante, essa unidade faz sentido se consideramos a problemática aqui analisada e os posicionamentos dos meus interlocutores, tanto do Brasil, como do Peru, diante dela. Obviamente, falar de coletivos que se sentem integrantes de um "povo único" Ashaninka em determinado contexto não exclui diferenças entre eles, como também veremos.

Os Ashaninka habitam, principalmente, a área central do território dos Arawak subandinos, na região peruana conhecida como Selva Central, considerada seu território "tradicional". ${ }^{4}$ Segundo evidências arqueológicas, esse ramo oriental da família Arawak teria migrado dos arredores da atual cidade de Manaus e se instalado no Ucayali há cerca de 5 mil anos (Lathrap, 1970). O crescimento da população e a pressão dos Pano, que chegaram posteriormente à região, teriam progressivamente empurrado esses grupos Arawak até as cabeceiras do Ucayali e seus principais afluentes, encostando-os também no piemonte oriental da cordilheira central dos Andes (Hill e Santos-Granero, 2002: 29). Hoje, no Peru, os Ashaninka estão em seis regiões: Ayacucho, Junín, Ucayali, Pasco, Cuzco y Huánuco. Vivem, majoritariamente, em mais de quatrocentas comunidades nativas situadas no planalto do Gran Pajonal e na região do curso alto do rio Ucayali, no baixo Urubamba, Tambo, Ene, Pichis, Pachitea e baixo Apurimac. No Acre, os Ashaninka estão presentes em sete terras indígenas, todas situadas na bacia hidrográfica do Alto Juruá. ${ }^{5}$

Arbitrariamente separados pelas fronteiras dos Estados-nações, os Ashaninka se consideram um povo único, diferente dos outros indígenas, mas também dos brancos brasileiros e peruanos. Veremos, adiante, que esse sentimento identitário comum que transcende as fronteiras geopolíticas nacionais não significa que as marcas dos Estados não estejam presentes em seus discursos e maneiras de ver o mundo. Por hora, cabe refletir sobre esse sentimento de união que transcende a fronteira definida pelos 
brancos. A ideia de pertencimento a um povo único se expressa na própria autodenominação desse povo indígena, mas os Ashaninka nem sempre foram reconhecidos como tal e seu etnônimo ainda é sujeito a controvérsias que merecem alguns esclarecimentos para justificar o meu uso do termo "Ashaninka".

Durante muito tempo, os Ashaninka foram conhecidos como Campa no Peru ou Kampa no Brasil. Existem muitas especulações sobre a origem desse nome que foi muito utilizado, de maneiras distintas, por missionários, cronistas, funcionários governamentais, historiadores e antropólogos até a década de 1980. De modo geral, o termo Campa foi usado para designar diferentes grupos Arawak dessa região que se assemelhavam pelo idioma, pelos adereços, principalmente a vestimenta, ou simplesmente o modo de vida. Assim, em função dos autores, o termo pôde se referir ao povo Ashaninka de forma genérica, a alguns Arawak subandinos em específico ou até ao conjunto etnolinguístico como um todo.

Na região do Alto Juruá brasileiro, o termo kampa (grafado com k) foi usado correntemente pelos próprios Ashaninka do Amônia até o início da década de 1990, de tal forma que consta no registro oficial de seu território: Terra Indígena Kampa do Rio Amônia. Embora não seja mais utilizado pela APIWTXA, ele continua fazendo parte do léxico dos brancos da região que ainda o usam para se referir aos índios do Amônia. Quando indagados sobre seu significado, os regionais dizem que a palavra teria surgido do costume desse povo de acampar nas praias dos rios no período estival. Em Pucallpa, o professor e liderança ashaninka, Jeribati Diquez, levantou a hipótese de que esse nome poderia ser derivado da palavra campo, empregada pelos missionários para designá-los, ainda na época colonial, em razão de sua resistência aos trabalhos agrícolas. Segundo Varese (1973: 140), o termo teria sido imposto aos Ashaninka por vizinhos Arawak ou Pano do Ucayali. Já Alvarez (1981: 30) afirma que teria sido dado pelos Yine do rio Urubamba.

Para os Ashaninka do Peru, como para os do Brasil, o termo Campa ou Kampa é considerado uma denominação exógena que nada significa. De modo geral, eles desconhecem sua origem e a consideram, principalmente no Peru, como extremamente pejorativa. ${ }^{6}$ Querem ser chamados de Ashaninka e ser vistos como um povo único, independentemente da fronteira internacional que os dividiu.

Se o termo Campa é hoje veementemente rejeitado por esse povo indígena e foi progressivamente abandonado, tanto pelos acadêmicos, como nos documentos oficiais, ainda existem muitas controvérsias sobre os etnônimos, principalmente, em relação aos termos "Ashaninka" e "Asheninka". A questão central consiste em 
saber se são povos diferentes, até que ponto são diferentes e se é pertinente juntá-los sob uma denominação mais genérica. Nos meus trabalhos, venho adotando o termo "Ashaninka" como uma denominação "guarda-chuva" que engloba tanto os Ashaninka, quanto os Asheninka. Estou ciente que essa opção pode ser legitimamente contestada. De fato, embora haja uma compreensão mútua, existem diferenças linguísticas e, em menor grau, culturais entre os dois grupos. Essas diferenças fazem com que sejam geralmente apresentados como povos distintos, contendo, inclusive, variações internas: diferenças dialectais em função da região, etc. Desse modo, considerar Ashaninka e Asheninka como um "povo único" não deixa de ser problemático, principalmente, no contexto etnográfico da Amazônia peruana. Esse englobamento não deve ser visto simplesmente como uma questão de preciosismo acadêmico ou um equívoco etnográfico. Trata-se, também, de uma opção que pode ser interpretada como politicamente arriscada. Por exemplo, os índios do Pajonal rejeitam o termo Ashaninka e fazem questão de ser chamados de Asheninka (Hvalkof e Veber, 2005: 102). O mesmo ocorre com muitas comunidades da região de Atalaya, onde os Asheninka procuram diferenciar-se da hegemonia dos Ashaninka, muito mais numerosos em termos demográficos, e reivindicam do governo o reconhecimento de suas particularidades linguísticas e culturais, por exemplo, nas discussões sobre políticas educacionais destinadas aos povos indígenas. Em termos linguísticos, também seria mais adequado se referir aos índios da Terra Indígena Kampa do Rio Amônia como “Asheninka”, já que a grande maioria das famílias é Asheninka, sendo uma minoria Ashaninka (menos de 20\% da população local). Por essa razão, as cartilhas da escola da aldeia Apiwtxa usam a grafia asheninka.

A minha opção pelo termo Ashaninka como denominação genérica explica-se por duas razões principais. Primeiro, entre os índios do Rio Amônia, o termo Ashaninka se consolidou progressivamente na política interétnica a partir dos anos 1990 e é o único comumente usado pela APIWTXA para se referir tanto ao seu povo no Rio Amônia, como aos seus semelhantes que vivem do outro lado da fronteira, sejam eles Ashaninka ou Asheninka. Em segundo lugar, durante o meu trabalho de campo no Peru, na região do Yuruá e na cidade de Pucallpa, os meus interlocutores indígenas foram unânimes em afirmar que Ashaninka e Asheninka formam um "povo único". Evidentemente, sabem das diferenças entre eles, mas consideraram-nas insignificantes e irrelevantes nas relações interétnicas ou, pelo menos, quando abordam sua separação em dois Estados nacionais.

Seja como for, podemos afirmar que os Ashaninka se consideram como integran- 
tes de um "povo único" que foi arbitrariamente dividido pelos Estados nacionais em decorrência das contingências históricas da economia da borracha. Em ambos os lados da fronteira, tratam-se como "irmãos" ou "parentes" que partilham a mesma língua, a mesma cultura e uma história em comum caracterizada por uma resistência tenaz às políticas coloniais dos brancos. Seja ele espanhol, peruano ou brasileiro, o branco é um inimigo comum que procura impor seu modo de vida e, há quase cinco séculos, cobiça seus territórios.

O etnônimo "Ashaninka" expressa essa unidade do povo. Para se referir a um Ashaninka do outro lado da fronteira internacional ou de outra terra indígena do Alto Juruá brasileiro, um indivíduo do Rio Amônia usará o termo "nosheninka", palavra composta pelo prefixo inclusivo da primeira pessoa do singular ("no" /“meu”) e a raiz "sheninka” que significa "parente”, "família”, “gente”, "povo”, ou seja, o termo em português pode ser traduzido por "meu parente", "meu familiar", "minha gente", "meu povo". Com o prefixo inclusivo da primeira pessoa do plural "a” ("nós"), a palavra "asheninka” (ou ashaninka) pode ser traduzida como "nós, os parentes" ou "nós, a família”. Na literatura etnográfica, o termo também pode aparecer com o significado de "os homens”, “a gente”, “o povo”, “os irmãos”, “os compatriotas”, etc. No Rio Amônia, os Ashaninka preferem ser mais literais e traduzir seu etnônimo por: "nós, a família”, "nós, os parentes", "nós, o povo" ou ainda "uma família só”, "um povo único".

Para expressar sua identidade étnica específica e construir as fronteiras, no sentido de Barth (1969), entre eles e os diferentes outros, sejam eles indígenas ou não indígenas, vários aspectos sociais e culturais podem ser elencados: vínculos de parentesco, língua, religião, adornos, modos alimentares, história, valores morais, etc. Entre esses elementos, a vestimenta tradicional de algodão, tecida pelas mulheres no tear, conhecida como cushma (ou kushma no Brasil) e na língua nativa como kitharentsi, é, certamente, o mais forte dos símbolos identitários. Assim, diferentemente dos brancos e dos outros índios, os Ashaninka são aqueles que vestem a kitharentsi. Embora a vestimenta não seja usada permanentemente, ela é muito comum nas aldeias. ${ }^{7}$ Abandonar definitivamente o uso da kushma é ter vergonha de sua identidade, querer ser confundido com outros índios ou simplesmente desejar "virar branco".

\section{Exploração madeireira e narcotráfico: a fronteira como ameaça}

No início dos anos 2000, atendendo a pressões econômicas do setor madeireiro, 
o governo peruano concedeu 7,5 milhões de hectares de floresta amazônica para a exploração madeireira. As concessões florestais transformaram cerca de $30 \%$ da Amazônia peruana em "Bosques de Producción Permanente", metade dessas áreas situadas na fronteira do Peru com o Brasil. No Departamento do Ucayali, por exemplo, a madeira tornou-se o principal recurso florestal e sua exploração, intimamente vinculada ao poder político, domina a economia regional. ${ }^{8}$ Além das concessões florestais, o Peru também destacou grande parte de seu território amazônico para a prospecção e exploração de petróleo e gás. A busca frenética por madeira e a exploração de petróleo e gás são os exemplos mais salientes de uma série de projetos governamentais e de medidas legislativas contra os direitos indígenas que resultaram na intensificação dos conflitos socioambientais na Amazônia peruana. ${ }^{9}$

Em outra ocasião (Pimenta, 2012b), tive a oportunidade de apresentar um panorama das ameaças aos direitos e territórios indígenas que atingem a fronteira Brasil-Peru na região do Acre-Ucayali e do Alto Juruá em particular. Entre essas ameaças, além de atividades ilegais como o narcotráfico, há projetos de desenvolvimento e de integração fronteiriça entre os dois países, baseados na exploração frenética dos recursos naturais, na construção de estradas, etc. Embora essas políticas sejam mais efetivas do lado peruano, o Brasil também participa ativamente deste cenário.

Nesse contexto regional, os Ashaninka do Rio Amônia, conscientes dos limites de sua terra indígena, também concebem a fronteira internacional como uma ameaça. Para ilustrar alguns dos perigos que rondam a fronteira, limitar-me-ei ao relato de dois exemplos ocorridos no lado peruano, na área limítrofe à Terra Indígena Kampa do Rio Amônia. Os dois casos envolveram diretamente os Ashaninka de Apiwtxa com duas comunidades, também ashaninka, situadas em território peruano: a Comunidad Nativa Sawawo - Hito 40, no primeiro caso, e a Comunidad Nativa Alto Tamaya - Saweto, no segundo.

A exploração madeireira na Amazônia peruana se fez, algumas vezes, com a cumplicidade ou omissão de lideranças indígenas que, por falta de alternativas econômicas, acabaram autorizando a entrada de madeireiros em suas terras. Esse foi o caso da Comunidad Nativa Sawawo - Hito 40. Situada no Rio Amônia, em território peruano, imediatamente após o marco fronteiriço, a cerca de cinco horas de viagem em canoa motorizada da aldeia Apiwtxa, essa comunidade ashaninka foi criada, em 1994, por algumas famílias indígenas que viviam do lado brasileiro e foram atraídas por promessas assistencialistas do governo peruano, desejoso de marcar sua presença na fronteira internacional no Rio Amônia. A essas famílias, que mantêm 
estreitos laços de parentesco com os Ashaninka de Apiwtxa, juntaram-se outros Ashaninka do Peru e a comunidade foi oficialmente reconhecida como comunidad nativa em janeiro de 1999, com um território de 35 mil hectares. ${ }^{10}$

A partir do final dos anos 1990, os Ashaninka de Sawawo começaram a ser seduzidos por empresas madeireiras. Mediante promessas de planos de manejo sustentáveis e futuros reflorestamentos, nunca cumpridos, as lideranças de Sawawo obtiveram do Instituto Nacional de Recursos Naturais do Peru (INRENA) a permissão para explorar madeira em seu território e firmaram um contrato com a madeireira Forestal Venao. Em poucos anos, centenas de árvores da Comunidad Nativa Sawawo Hito 40 foram derrubadas.

A empresa não limitou suas atividades ao território peruano. A APIWTXA acusou a Forestal Venao de ter sido a principal responsável por invasões periódicas à Terra Indígena Kampa do Rio Amônia e ao Parque Nacional da Serra do Divisor, no início dos anos 2000. A associação indígena foi a primeira a denunciar essas invasões que ganharam uma grande repercussão na imprensa nacional e internacional. As incursões de madeireiros peruanos em território brasileiro causaram danos ambientais na Terra Indígena Kampa do Rio Amônia e levaram a tensões nas relações entre os Ashaninka de Apiwtxa e de Sawawo (Pimenta, 2012a). A mobilização da APIWTXA levou a Polícia Federal e o Exército brasileiros a intensificar a fiscalização e o monitoramento dessa região de fronteira internacional, com o apoio dos índios. ${ }^{11}$

Entre 2001 e 2007, a questão das invasões madeireiras ao território brasileiro foi um tema importante na agenda de negociações bilaterais entre Brasil e Peru em torno das políticas de integração fronteiriça, tanto nacionalmente, como regionalmente. Em março de 2005, em Lima, o líder Benki Piyãko, da APIWTXA, cobrou diretamente do então presidente do Peru, Alejandro Toledo, a interrupção imediata das invasões madeireiras no Alto Juruá e garantias para a proteção do meio ambiente e das populações indígenas da região de fronteira.

Aos poucos, as invasões diminuíram a partir de 2007, com o fim das atividades da Forestal Venao na Comunidad Nativa Sawawo - Hito 40. No entanto, madeireiros ilegais e narcotraficantes continuaram atuando na região do Alto Tamaya, um afluente do rio Ucayali, nos arredores da comunidade ashaninka de Saweto. ${ }^{12}$ Em 2014, essa comunidade, cujo território também faz fronteira com a Terra Indígena Kampa do Rio Amônia, foi vitimada por uma tragédia que mobilizou a mídia internacional e exemplifica a violência que caracteriza essa região de fronteira.

No primeiro dia de setembro de 2014, quatro lideranças ashaninkas de Saweto 
viajavam à aldeia Apiwtxa para participar de uma reunião na qual discutiriam estratégias de vigilância da fronteira para impedir o corte ilegal de madeira e o narcotráfico. As aldeias de Apiwtxa e Saweto são conectadas por uma trilha florestal, percorrida em cerca de oito horas. Como no caso de Sawawo, laços de parentesco também unem famílias dessas duas comunidades. Ao longo dos anos, ambas também construíram uma sólida aliança política para enfrentar as ameaças a seus territórios. A comitiva de Saweto nunca chegaria ao destino. Após alguns dias de espera, preocupados com a demora de seus parentes e amigos, um grupo de homens de Apiwtxa decidiu percorrer o caminho em sentido contrário. Numa área de repouso, situada do lado peruano, na margem do rio Putaya, afluente do Tamaya, a cerca de uma hora e meia da linha de fronteira, encontraram pertences das lideranças e partes de seus corpos.

Dadas as dificuldades de comunicação, os assassinatos das quatro lideranças de Saweto só foram comunicados por radiofonia pelos líderes da APIWTXA no dia 7 de setembro. A notícia ganhou rapidamente as redes sociais e a imprensa internacional, chegando a ser divulgada por jornais de renome, como The NewYork Times e The Guardian. Entre os Ashaninka assassinados, estava Edwin Chota Valera, fundador da Associação das Comunidades Nativas Ashaninka / Asheninka de Masisea e Calleria (ACONAMAC) e principal liderança de Saweto.

Edwin Chota era um dos principais aliados da APIWTXA. Era muito conhecido na região do Ucayali por sua incansável luta contra a exploração ilegal de madeira e o narcotráfico que, muitas vezes, se confundem nas áreas de fronteira. Há anos, reivindicava do governo peruano a titulação de seu território como comunidad nativa e denunciava, periodicamente, as ameaças de mortes que recebia. Com o apoio de David Salisburry, professor de geografia da Universidade de Richmond nos Estados Unidos, sua luta ganhou destaque internacional sendo, por exemplo, matéria da revista National Geographic em abril de 2013. ${ }^{13}$

A crueldade e covardia dos assassinos das quatro lideranças de Saweto geraram uma profunda indignação e revolta na sociedade peruana. A mobilização da mídia, a repercussão internacional e as pressões decorrentes colocaram as autoridades peruanas na berlinda. As investigações oficiais confirmaram que as lideranças de Saweto tinham sido vítimas de uma emboscada de madeireiros ilegais que se sentiam ameaçados em suas atividades pelas denúncias constantes dos Ashaninka. Um brasileiro da cidade de Marechal Thaumaturgo, que atuava na região do Tamaya, foi preso, acusado de ser um dos autores do massacre, mas liberado meses depois. ${ }^{14}$ O governo peruano também nomeou uma comissão para investigar o corte ilegal 
de madeira ao longo da fronteira internacional e anulou algumas concessões florestais na região. A APIWTXA, junto com associações indígenas peruanas e ONGs, continuou mantendo pressão sobre o governo peruano, exigindo justiça e a titulação do território indígena. Após a tragédia, um grupo de lideranças femininas dessa comunidade, que passou a ser referido como as "viúvas de Saweto", ganhou projeção internacional com o apoio da Rainforest Foundation US, que passou a ajudar os Ashaninka de Saweto. Entre essas mulheres, Diana Rios, filha de Jorge Rios, um dos Ashaninka assassinados, e ex-esposa de Edwin Chota, tornou-se a principal porta-voz da comunidade. No dia 17 de novembro de 2014, ela recebeu, em Nova Iorque, o prêmio de ativismo ambiental da Alexander Soros Foundation que homenageou a luta da comunidade. Em agosto de 2015, cerca de um ano após os assassinatos, as "viúvas de Saweto", acompanhadas por lideranças da APIWTXA, receberam, em Pucallpa, o título definitivo do território pelo qual lutavam desde 2003. A Comunidad Nativa Alto Tamaya - Saweto foi titulada com uma área de cerca de 80 mil hectares, território considerado "generoso" quando comparado ao tamanho médio das comunidades indígenas da Amazônia peruana.

Após a comoção inicial dos assassinatos e a titulação da comunidade, os Ashaninka de Saweto deixaram os holofotes e voltaram ao esquecimento. ${ }^{15}$ As circunstâncias exatas da chacina que vitimou Edwin Chota e seus três companheiros nunca foram esclarecidas. Seus autores continuam desconhecidos e impunes. Em setembro de 2017, em sua página na internet, a Rainforest Foundation US anunciou o arquivamento do inquérito pela Procuradoria de Pucallpa por falta de provas.

\section{Alianças ashaninkas transnacionais: a fronteira que une}

As invasões madeireiras em Sawawo e os assassinatos das lideranças de Saweto tornaram-se emblemáticos das ameaças vividas pelas comunidades ashaninkas dessa região de fronteira internacional. Diante dessa conjuntura, as lideranças da APIWTXA mobilizaram aliados para deter as investidas desses grupos criminosos em seus territórios. A associação dos Ashaninka do Rio Amônia tem sido a principal protagonista de articulações políticas no Alto Juruá e na região de fronteira com o Peru que visam preservar a integridade dos territórios protegidos, combater as atividades ilegais e fomentar alternativas econômicas sustentáveis aos projetos desenvolvimentistas governamentais. Nos últimos anos, dentro dessa agenda, ela procurou unificar o povo Ashaninka dos dois lados da fronteira. No entanto, é importante frisar que a agenda indígena transnacional não se limita à unificação do 
povo Ashaninka. A estratégia da APIWTXA, como mostrei anteriormente, tem sido integrar todos os seus vizinhos, Ashaninka ou não, indígenas e não indígenas, num esforço comum para implementar uma política abrangente de desenvolvimento sustentável para toda a bacia do Alto Juruá. Ou seja, as alianças entre os Ashaninka dos dois lados da fronteira Brasil-Peru são um aspecto importante, mas não único, de uma agenda política maior da APIWTXA para essa região. Focalizarei, a seguir, essas alianças intraétnicas transnacionais, mas é importante ter em mente que elas também se articulam com alianças interétnicas transfronteiriças. ${ }^{16}$

Como visto anteriormente, apesar de uma nova concepção do território e da fronteira internacional, decorrente da demarcação da Terra Indígena Kampa do Rio Amônia, os índios de Apiwtxa nunca deixaram de manter contato com os Ashaninka do Peru. Até o início dos anos 2000, essas relações eram geralmente baseadas em laços de parentesco e amizade, que continuam existindo. Com as ameaças fronteiriças, exemplificadas pelos eventos ocorridos em Sawawo e Saweto, os contatos entre os Ashaninka dos dois lados da fronteira adquiriram uma dimensão mais política e institucional. A aliança transnacional tornou-se, hoje, uma prioridade das lideranças da APIWTXA.

Entre os Ashaninka da aldeia Apiwtxa, a ideia de se unir com seus parentes que vivem no Peru é um sonho antigo. Por se considerarem um povo único, que compartilha uma cultura e uma história, as alianças intraétnicas entre os Ashaninka são, de certa forma, naturalizadas nos discursos. Essa visão também está presente entre os Ashaninka do Peru. Raul Casanto Shingari, por exemplo, uma liderança da Comunidad Nativa de Paititi, situada no rio Huacapishtea, afluente de margem esquerda do Juruá, compartilha com entusiasmo desse ideal. Em 2004, ele fundou a Associação Regional do Povo Ashaninka do Ucayali (ARPAU) da qual é presidente. A associação nasceu com o desafio inicial de unificar quase 150 comunidades ashaninka dessa região. Segundo Raul, embora inicialmente limitada ao Ucayali, a ARPAU era um primeiro passo para a criação de uma futura federação dos Ashaninka do Peru que, por sua vez, devia ampliar-se para reunir todos os Ashaninka além da fronteira internacional, ou seja, incluir também os Ashaninka do Brasil. É difícil saber até que ponto o ideal de união étnica transfronteiriça desse povo estava, realmente, presente na criação da ARPAU ou se é uma reconstrução discursiva a posteriori feita numa conjuntura onde essa possibilidade de aliança ganha contornos mais definidos. O importante é que essa aspiração à união do povo Ashaninka, para além e apesar da fronteira internacional, numa espécie de "Federação Ashaninka Transnacional”, 
é hoje um anseio compartilhado por todos os meus interlocutores, tanto no Brasil, como no Peru.

Na prática, a ARPAU nunca chegou a caminhar na direção de uma união pan-ashaninka. Como a grande maioria das associações indígenas peruanas do Ucayali com as quais tive contato, ela enfrenta enormes problemas de funcionamento. Sem recursos financeiros, existe somente em termos formais, sem estrutura, nem atuação concreta. A situação da ARPAU contrasta fortemente com a experiência da APIWTXA de mais de duas décadas no mercado de projetos de desenvolvimento sustentável. Com o reconhecimento conquistado, esta última começou a edificar as bases para unir o povo Ashaninka para além da fronteira internacional. O que a ARPAU sonhou, a APIWTXA iniciou.

Nos últimos anos, com o apoio de vários parceiros, como a CPI-Acre, os Ashaninka do Rio Amônia intensificaram seus encontros com comunidades e associações ashaninkas situadas do lado peruano, procurando unir seus parentes. Em abril de 2015, no âmbito do Programa Fundo Amazônia, a APIWTXA foi contemplada com o "Projeto Alto Juruá", financiado pelo BNDES no valor total de 6,6 milhões de reais. ${ }^{17}$ Embora não seja seu foco principal, esse projeto inclui uma agenda política transfronteiriça importante, na medida em que prevê ações dirigidas a seis comunidades ashaninkas peruanas da região fronteiriça. ${ }^{18}$

Entre 17 de julho e 3 de agosto de 2015, movidas pelo desejo de resgatar e aprofundar os conhecimentos sobre sua história e espiritualidade, lideranças da APIWTXA, acompanhadas por representantes ashaninkas do Peru, também empreenderam a "Expedição Tsonkiri" (Beija-flor), cujo principal objetivo era a realização de um mapeamento preliminar de alguns sítios sagrados desse povo na região da Selva Central, ao longo dos rios Perene, Tambo e Alto Ucayali. Essa primeira viagem deu origem a um documentário e a um outro projeto intitulado "Expedição Yorenka Tasori" (Sabedoria do Criador) que, além de estimular novos intercâmbios entre os Ashaninka do Brasil e do Peru para o fortalecimento de sua cultura, busca criar iniciativas para proteger os sítios sagrados ashaninkas. Este segundo projeto está pronto desde 2017; as lideranças da APIWTXA procuram atualmente os recursos financeiros necessários para sua realização.

$\mathrm{O}$ auge dessas articulações transfronteiriças entre os Ashaninka foi a realização do I Congresso Binacional do Povo Ashaninka-Asheninka Brasil/Peru, em Pucallpa, nos dias 21 e 22 de setembro de 2015, organizado numa parceria entre a APIWTXA e organizações indígenas peruanas. Durante os dois dias do encontro, cerca de 130 
lideranças ashaninkas dos dois países se reuniram para identificar os problemas vividos por suas comunidades e discutir estratégias de luta e de fortalecimento de seus direitos. Nesse encontro, as lideranças da APIWTXA compartilharam com seus parentes do Peru a história de sua comunidade, relataram suas experiências com a exploração madeireira e as iniciativas de desenvolvimento sustentável que buscam implementar no Alto Juruá. Após esse encontro, foi criada uma comissão binacional encarregada da preparação de um segundo congresso. Inicialmente programado para ocorrer em outubro de 2016, na cidade de Satipo, na região de Junin, ele ainda aguarda financiamento.

É interessante notar que essas articulações ashaninkas transnacionais não apresentam somente um aspecto político de luta contra os projetos desenvolvimentistas dos Estados nacionais e ultrapassam a região de fronteira. O desejo de união do povo Ashaninka também tem uma importante dimensão de fortalecimento cultural e trocas de experiências, que se traduz em alianças com comunidades ashaninkas situadas em regiões mais distantes da Amazônia peruana. Essa dimensão cultural é saliente, por exemplo, nas expedições aos sítios sagrados que visam conhecer e proteger lugares essenciais da história e espiritualidade do povo Ashaninka que a maioria da população indígena do Rio Amônia só conhece pela tradição oral. $\mathrm{Na}$ aldeia Apiwtxa, os moradores também já receberam delegações ashaninkas dos rios Ene, Tambo e Alto Perene. Parentes peruanos da região de fronteira, mas também de lugares mais distantes, são sempre convidados para participar das festividades de comemoração do aniversário de demarcação da Terra Indígena Kampa do Rio Amônia que ocorre anualmente no mês de junho. Em 2015, a APIWTXA e a Comunidad Nativa San Miguel, situada na Província de Chanchamayo, na região de Junin, firmaram um convênio para intercâmbio cultural. Esses encontros e intercâmbios constituem ocasiões importantes para discutir política e estratégias de luta diante das ameaças dos brancos, mas também momentos privilegiados para falar de cultura, tradição, história, xamanismo, língua, etc.

\section{Sentidos e desafios da união transnacional ashaninka: a fronteira que diferencia}

Tenho poucas informações sobre as reações das autoridades governamentais brasileiras e peruanas às alianças entre os Ashaninka dos dois países. Talvez por ter ocorrido em território peruano, o primeiro congresso Ashaninka binacional parece não ter suscitado qualquer interesse do Brasil. No Peru, as reações oficiais também 
foram discretas. Segundo lideranças ashaninkas, o governo do Ucayali chegou a demonstrar perplexidade com o caráter binacional do evento, algo inédito na região. Pediu esclarecimentos sobre seus objetivos, mas não dificultou, nem interferiu na sua organização. É importante lembrar que o encontro aconteceu no mês seguinte à entrega do título definitivo à Comunidad Nativa Alto Tamaya - Saweto pelas autoridades peruanas, ou seja, num contexto onde os Ashaninka estavam novamente sob os holofotes e qualquer manifestação contrária ao evento poderia ser politicamente arriscada. De qualquer forma, lideranças ashaninkas do Peru dizem que não perceberam reações contrárias por parte das autoridades peruanas. Segundo uma delas, o Governo do Ucayali teria até oferecido apoio com dois ônibus para transportar os Ashaninka da região de Pucallpa até Satipo, para viabilizar sua participação no segundo congresso binacional.

A maior preocupação veio de onde menos se esperava, isto é, do próprio movimento indígena da Amazônia peruana, principalmente, da AIDESEP e da ORAU, sua seção regional. ${ }^{19}$ Embora tenham apoiado a realização do congresso, vários líderes ashaninkas afirmaram que dirigentes dessas duas organizações teriam demonstrado inquietação com a organização de um encontro ashaninka binacional. Assim, um dos dirigentes da ORAU teria se dirigido a um líder ashaninka peruano para inquiri-lo nos seguintes termos: "O que vocês querem com esse congresso? Querem dividir o movimento indígena? Nós já temos uma organização nacional, temos uma organização regional, o que vocês querem?” Às perguntas, o líder ashaninka respondeu: “Não, não queremos dividir. Queremos é unir. Queremos unir o povo Ashaninka. Temos o maior número de índios do Peru e sequer estamos organizados até hoje”.

Embora ainda tímidas até agora, a perplexidade e inquietação tanto dos governos como das organizações indígenas peruanas diante das iniciativas de união binacional dos Ashaninka são compreensíveis. O desejo desse povo indígena para se aliar dos dois lados da fronteira é movido por um forte sentimento étnico, de fortalecimento e valorização cultural, mas também tem uma clara dimensão política que precisa ser explicitada. Afinal, qual é o sentido político que os Ashaninka do Brasil e do Peru dão à sua aspiração de união étnica transnacional?

De modo geral, o desejo dos Ashaninka em se unir para além da fronteira dos Estados-Nação é movido pela necessidade de se organizar e se fortalecer diante das políticas governamentais e não governamentais que os ameaçam. Como penso ter deixado evidente nas páginas anteriores, a união ashaninka transnacional é, sobretudo, uma reação às políticas desenvolvimentistas que atingem seus territórios e 
afetam seus modos de vida. Assim, à pergunta "Por que se juntar dos dois lados da fronteira?", as respostas são invariavelmente as mesmas: "para termos mais poder", "para sermos ouvidos", "para protegermos os nossos territórios”, "para termos nossas reivindicações atendidas” etc. Nesse contexto, os Ashaninka do Peru destacam a importância da APIWTXA que conseguiu conquistar seu espaço político e tornar-se um interlocutor respeitado pelas autoridades brasileiras. A associação dos Ashaninka do Rio Amônia só suscita elogios. Todos dizem admirar sua trajetória, olham para ela com entusiasmo e respeito, veem nela uma inspiração e um modelo a ser seguido. ${ }^{20}$

Enquanto, no Brasil, a APIWTXA conquistou, paulatinamente, uma posição de destaque que lhe permite delinear seu futuro de modo mais otimista e com grande liberdade, a união, para os Ashaninka do Peru, é um meio para conquistar maior autonomia tanto em relação ao Estado, como em relação às organizações indígenas interétnicas e à hegemonia dos Shipibo no Ucayali, da qual falarei adiante. Para os Ashaninka de ambos os lados da fronteira, o sentido de autonomia não deve ser confundido com qualquer aspiração à independência política. O sentimento compartilhado de formarem um povo único nunca se traduz em qualquer pretensão separatista. Os Ashaninka não só consideram que qualquer iniciativa nesse sentido está condenada ao fracasso, como também se percebem, como mostrarei adiante, como brasileiros ou peruanos. Assim, embora possam, às vezes, afirmar que formam uma "nação", esse termo não deve ser apreendido em seu sentido político separatista. Como salientaram Bartolomé (1998) e Brysk (2000), as noções de autonomia e autodeterminação reivindicadas pelos índios da América Latina devem ser consideradas como direitos humanos fundamentais que visam o reconhecimento do direito à existência desses povos como sujeitos coletivos, mas não significam secessão, isolamento ou questionamento da soberania dos Estados-nacionais. O desejo de autonomia dos povos indígenas procura abolir a tradição integracionista e homogeneizadora dos Estados, que devem assumir definitivamente sua pluralidade interna e promover transformações estruturais para buscar novas formas de convivência política mais igualitárias entre grupos culturalmente diferenciados dentro de um Estado realmente pluriétnico (Bartolomé, 1998: 185-186).

Assim, os Ashaninka, como os Yanomami (Ramos, 1996) e outros povos indígenas, não demonstram qualquer disposição para reivindicar uma independência política; ideia que eles consideram totalmente descabida. Ao contrário, lutam para conquistar maior autonomia dentro de seus respectivos Estados; uma autonomia que 
lhes possibilite viver em paz em seus territórios e decidir sobre os caminhos de seu próprio futuro. Esses caminhos, aliás, nunca são vistos como únicos, porque as realidades das comunidades locais também podem ser extremamente diversas. Assim, quando se referem às suas relações com os Estados nacionais, a palavra "respeito" torna-se onipresente: "queremos respeito", "exigimos respeito", "lutamos por mais respeito”, etc. Antes de analisar as percepções dos Ashaninka sobre seus Estados nacionais respectivos e discutir a ideia de nacionalidade e cidadania, cabe esclarecer as relações dos Ashaninka do Ucayali com as organizações indígenas interétnicas regionais, principalmente a AIDESEP e ORAU, já que, entre estes, o desejo de fortalecimento político e a busca por maior autonomia não diz respeito apenas ao Estado peruano. ${ }^{21}$

Para os Ashaninka do Ucayali, a união do povo é também uma maneira de conquistar mais autonomia em relação à ORAU e AIDESEP.Várias lideranças demonstraram seu desconforto com essas organizações indígenas multiétnicas, consideradas ineficazes para atender às suas reivindicações específicas. Salientaram o excessivo centralismo do poder político nas mãos dos Shipibo e a falta de atenção concedida historicamente às comunidades ashaninkas pela ORAU. Com efeito, desde a sua criação, essa associação tem sido dominada pelos Shipibo, habitantes das margens do rio Ucayali, mais numerosos na região de Pucallpa e muito mais articulados na política interétnica que os Ashaninka. Até recentemente, nenhum ashaninka tinha sido presidente da ORAU. ${ }^{22}$ Para exemplificar o desinteresse da associação indígena regional com seus problemas, os Ashaninka do Ucayali mencionam, justamente, o caso de Saweto. Assim, afirmam que, quando Edwin Chota era presidente da ACONAMAC, a ORAU nunca deu qualquer atenção às demandas territoriais da comunidade ashaninka de Saweto. Como o governo peruano, ela só começou a se interessar pela situação dessa comunidade após os assassinatos das quatro lideranças e a consequente midiatização da tragédia.

Assim, para os Ashaninka de Ucayali, unir seu povo é também uma maneira de conquistar mais visibilidade política dentro do próprio movimento indígena peruano, cuja história recente tem sido marcada por várias crises e divisões internas: líderes indígenas acusados de falta de representatividade, influências político-partidárias, problemas de administração de recursos, falta de transparência, etc. Ao se referir ao primeiro congresso binacional do povo Ashaninka, várias lideranças destacaram não só a dimensão internacional desse evento, mas também sua importância nacional para os Ashaninka do Peru. Consideraram que um de seus pontos 
positivos foi possibilitar o encontro de lideranças ashaninkas peruanas de diversas regiões que puderam conversar sobre seus problemas e anseios. Agradeceram a iniciativa da APIWTXA por ter possibilitado essa reunião que resultou no desejo de criar uma associação ou federação nacional dos Ashaninka do Peru. Segundo Raul Casanto, presidente da ARPAU, associação dos Ashaninka do Ucayali, todos os líderes ashaninkas do Peru desejam juntar esforços para a criação dessa entidade. Embora a ideia de uma organização Ashaninka binacional seja considerada importante para uma agenda internacional, afirmam que a pauta prioritária no Peru tem sido a organização política dos Ashaninka no plano nacional, um desejo que eles esperam materializar nos próximos anos.

Entre os Ashaninka do Brasil e os do Peru existem formas múltiplas de interrelações. Dinâmicas locais se articulam e se sobrepõem a dinâmicas nacionais e também globais. Essas articulações entre as esferas locais, nacionais e globais não são específicas dos Ashaninka e têm caracterizado a situação de muitos povos indígenas da América Latina nas últimas décadas (Brysk, 2000). Neste contexto, as regiões de fronteira, em sua dimensão geopolítica, isto é, como linha divisória entre Estados nações, também se tornam lugares privilegiados para observar as relações entre identidade étnica e nacionalidade (Cardoso de Oliveira, 2006). Em trabalho já mencionado (Pimenta, 2012a), tive oportunidade de me dedicar a esse tema, analisando as relações entre os Ashaninka da aldeia Apiwtxa no Brasil e seus vizinhos de Sawawo, no Peru. Nessa ocasião, mostrei que as relações entre identidade étnica e nacionalidade só faziam sentido quando relacionadas à dinâmica da conjuntura histórica e política em que essas duas comunidades estão inseridas. Assim, argumentei que todos os Ashaninka do Rio Amônia, tanto do lado brasileiro como do lado peruano, continuam afirmando a primazia do sentimento étnico sobre o sentimento nacional. Antes de tudo, eles se sentem e querem ser considerados Ashaninka, um "povo único", diferente dos outros índios e dos brancos, sejam eles brasileiros ou peruanos. No entanto, embora a identidade nacional esteja longe de apagar a identidade e a solidariedade étnica, não devemos concluir precipitadamente que ser Ashaninka no Brasil, pelo menos no Rio Amônia, e no Peru seja exatamente a mesma coisa. Não pretendo retomar aqui essa discussão, cujas conclusões permanecem válidas com a ampliação do campo etnográfico. Limitar-me-ei apenas a algumas considerações gerais.

O ideal político de unificação do povo ashaninka e a afirmação de uma identidade étnica transnacional não significa uma ameaça à soberania dos Estados-nações, nem 
uma negação das diferenças e do pertencimento nacional. Tanto no Brasil, como no Peru, os Ashaninka nunca negam que também são brasileiros ou peruanos. Reconhecem que mais de um século de separação entre os dois Estados também produziu diferenças entre eles. Dizem que, em cada país, eles têm "sua história específica" e "sua maneira de trabalhar". Embora devam aprender a lidar com processos desenvolvimentistas e integracionistas com características comuns, também estão conscientes de que pertencem a países diferentes, com legislações e políticas indigenistas distintas que causam impactos diferenciados dos dois lados da fronteira.

Em seus respectivos países, a maior parte dos Ashaninka vive quase diariamente as marcas de sua nacionalidade. Falam sua língua nativa, mas também o espanhol ou português. Receberam certidões de nascimento, documentos de identidade e, por vezes, aposentadorias ou subsídios diversos de programas governamentais. Todos esses elementos marcam sua inserção como cidadãos em países diferentes. Assim, o sentimento de pertencimento nacional pode se revelar quando falam de seu lugar de moradia ou nascimento. Uma de suas manifestações mais expressivas também ocorre, por exemplo, nos jogos de futebol que envolvem a seleção de seu respectivo país. A nacionalidade também se manifesta em solenidades oficiais onde se canta o hino e se presta tributo à bandeira, ocasiões pouco frequentes para os Ashaninka do Brasil, mas muito corriqueiras na sociedade peruana.

A escola é, certamente, a instituição que mais contribui para fomentar o sentimento nacional. Entre os Ashaninka do Ucayali, ela é apontada como a principal responsável por um processo de "peruanização" forçado e desrespeitoso de sua especificidade étnica e cultural. Muitos reclamam que faltam professores ashaninkas, que, em muitas escolas, o ensino é realizado exclusivamente em espanhol, que as crianças são obrigadas a cantar diariamente o hino nacional e saudar a bandeira, etc. É uma situação bem diferente da vivida pelos Ashaninka da aldeia Apiwtxa, cuja escola é pautada nos princípios político-pedagógicos da educação escolar específica e diferenciada, reconhecida e apoiada pelo estado brasileiro.

De modo geral, a avaliação feita sobre a escola também é projetada para outras esferas da vida social. Assim, os Ashaninka do Peru consideram que a situação de seus parentes no Brasil é consideravelmente melhor, não só em termos educacionais, mas também na questão dos direitos territoriais (terras indígenas maiores), na área de saúde (sistema de saúde diferenciado), no apoio às atividades produtivas, etc. No entanto, essas condições melhores são vistas, sobretudo, como decorrentes dos méritos da APIWTXA, de sua luta de resistência e capacidade organizativa, e 
menos como resultado de uma maior benevolência e atenção do Estado brasileiro em relação às populações indígenas. Assim, ouvi muitas lideranças Ashaninka do Peru lamentarem, em contraste com a APIWTXA, sua pouca visibilidade política e sua falta de poder diante do governo peruano. Embora sejam a grande maioria em termos demográficos, os ashaninka no Peru repetem constantemente que "não têm voz”, que “o Peru não respeita os Ashaninka”, que “o nosso país nos esqueceu”, que a "cultura está se perdendo”, etc. Nas palavras de Jeribati, professor e liderança ashaninka do Ucayali: "somos peruanos, mas peruanos da margem do Estado". Esse diagnóstico é compartilhado pelos Ashaninka da APIWTXA que também consideram que seus parentes peruanos "não têm voz", que estão "perdendo a cultura”, a língua, etc. Percebem que muitos têm vergonha de usar a kushma, que preferem dar valor às "coisas de branco" em detrimento de suas próprias tradições ou, simplesmente, que estão "virando brancos". Ou seja, todos os Ashaninka concordam que a situação no Peru é muito pior, principalmente, se comparada à vivida na Terra Indígena Kampa do Rio Amônia, mas também às outras áreas ashaninkas no Brasil. Falam dos problemas que afligem as comunidades peruanas com pessimismo, mas também veem na organização política de seu povo, na aliança transfronteiriça com a APIWTXA e na promissora união com seus semelhantes de outras regiões do Peru a esperança de construir um futuro melhor. O sonho de uma vida melhor e de uma maior autonomia, tanto em relação ao Estado como às associações indígenas peruanas, passa por um longo processo de união e organização política; processo que os ashaninka do Rio Amônia vivenciaram na luta contra a exploração madeireira e pela demarcação de sua terra; processo que a própria palavra apiwtxa expressa e simboliza: a necessidade de se juntar, de se unir.

\section{Conclusão}

As recentes alianças intraétnicas entre os Ashaninka do Brasil e do Peru apresentam uma dimensão, principalmente política, que tentei priorizar neste trabalho. Elas procuram o fortalecimento do povo Ashaninka diante dos Estados nacionais, mas apresentam características diferenciadas de ambos os lados da fronteira. Para os Ashaninka do Rio Amônia, que têm sido os principais protagonistas desse processo, elas integram um ideal político maior. Desde a demarcação da Terra Indígena Kampa do Rio Amônia, a estratégia etnopolitica da APIWTXA tem sido a construção de alianças com seus vizinhos, Ashaninka ou não, indígenas e não indígenas, brasileiros e peruanos, em busca de alternativas econômicas sustentáveis para essa 
região de fronteira ameaçada por atividades ilegais e por políticas desenvolvimentistas estatais, baseadas em grandes projetos de integração comercial e na exploração predatória de recursos naturais, principalmente, madeira e petróleo. Para os Ashaninka do Ucayali, as alianças com seus parentes do Brasil oferecem, sobretudo, uma oportunidade de estimular uma união dos Ashaninka, com amplitude nacional, para se fortalecer politicamente diante do Estado peruano e do movimento indígena regional no qual se sentem pouco contemplados.

Privilegiei a dimensão política das alianças entre os Ashaninka dos dois lados da fronteira, certamente, o aspecto mais saliente, mas, é importante lembrar, sobretudo no caso dos Ashaninka do Rio Amônia, que a construção e fortalecimento dos laços com seus parentes peruanos também é movido pelo desejo de recuperar e valorizar uma história e uma cultura comum e única. A geopolítica dos brancos impôs uma fronteira que, seguramente, diferencia os Ashaninka, mas, apesar de dividi-los, ela não conseguiu desuni-los. Embora impregnados por marcadores nacionais próprios de cada país, os Ashaninka, tanto do lado peruano, como do lado brasileiro, continuam se pensando como um povo único e diferenciado dos demais. Hoje, enquanto os Estados nacionais se articulam para além de suas fronteiras para implementar políticas desenvolvimentistas e atender aos interesses do mercado, ameaçando os territórios indígenas, os Ashaninka fortalecem sua união transfronteiriça para defender seus direitos, mas também valorizar sua história e cultura. Não lutam por uma soberania própria, mas por uma maior autonomia para construir sua história específica, dentro de seus territórios legalmente reconhecidos e pelo respeito às suas diferenças.

Por fim, se o caráter transnacional dessas alianças ashaninkas é, certamente, inédito, é interessante lembrar que elas também se apresentam, de certo modo, como a continuidade e ampliação de uma tradição política já consolidada na Amazônia peruana. Assim, se os Ashaninka demonstram um apreço muito grande pela ideia de liberdade e valorizam a autonomia local, eles também têm demonstrado historicamente uma extraordinária capacidade de resiliência que se traduz pela necessidade periódica de se unir a níveis supralocais. Alianças entre diferentes grupos ashaninka, que podem se desdobrar em alianças interétnicas com outros povos indígenas da Amazônia, ocorrem recorrentemente na história desse povo. Ainda no período pré-colombiano, os Ashaninka participaram ativamente, por exemplo, de alianças pan-étnicas que reuniam periodicamente os povos da Amazônia para rechaçar as tentativas expansionistas do Império incaico em direção ao oriente. Em 
meados do século XVIII, juntamente com outros povos indígenas da Amazônia, também participaram de uma ampla aliança interétnica liderada por Juan Santos Atahualpa, que expulsou os espanhóis da Selva Central peruana e impediu a entrada de colonos brancos na região durante quase um século (Renard-Casevitz, 1992). Por fim, mais recentemente, no final da década de 1980, os Ashaninka do Peru se uniram para expulsar os guerrilheiros do Sendero Luminoso e do Movimento Revolucionário Tupac Amaru, que atuavam em seus territórios e ameaçavam seu modo de vida. Estas coligações surgem periodicamente na história desse povo indígena em momentos de crise profunda. Um pouco ao modo dos Nuer (Evans-Pritchard, 1978), elas são temporais e circunstanciais. Formam-se quando as ameaças se intensificam e se desfazem rapidamente, assim que o perigo é afastado. Ainda incipientes, as atuais alianças transnacionais entre os Ashaninka do Brasil e do Peru parecem reatualizar essa tendência histórica.

Recebido: 07/05/2018

Aprovado: 02/07/2018

José Pimenta é professor do Departamento de Antropologia da Universidade de Brasília (DAN/UnB) e do Mestrado Profissional em Sustentabilidade junto a Povos e Terras Tradicionais do Centro de Desenvolvimento Sustentável da Universidade de Brasília (MESPT/UnB). Desenvolve pesquisas com os Ashaninka da região do Alto Juruá (Acre) desde 1998, tendo como foco de interesse os seguintes temas: etnologia indígena, indigenismo, desenvolvimento, sustentabilidade, relações interétnicas e questões fronteiriças. É membro fundador do Laboratório de Indigenismo e Etnologia Indígena (LINDE) do Departamento de Antropologia da Universidade de Brasília e coordenador, junto com a Profa. Alcida Rita Ramos, do Grupo de Pesquisa do CNPq “Etnologia e indigenismo”. Contato: josepimenta17@gmail.com 


\section{Notas}

1. Este artigo é resultado de diversas fases de trabalho de campo realizadas entre janeiro de 2014 e março de 2017 no âmbito do projeto de pesquisa "Povos indígenas, fronteiras e políticas nacionais”, coordenado por Alcida Rita Ramos e financiado pelo CNPq (Edital Universal 14/2012). Realizei pesquisa em Cruzeiro do Sul, na Terra Indígena Kampa do Rio Amônia, na Comunidad Nativa Sawawo Hito 40, no município peruano de Puerto Breu, na região do Yurua (Alto Juruá peruano), e também na cidade de Pucallpa, capital da região do Ucayali. Agradeço ao CNPq pelo financiamento que viabilizou esse projeto. Agradeço a Alcida Ramos e aos colegas que integraram o projeto pela sempre estimulante e proveitosa troca de ideias. Agradeço, também, a Alexandrina Pinhanta (Shãtsi), liderança Ashaninka do Rio Amônia, por ter facilitado os contatos com lideranças ashaninka do Ucayali e por ter me acompanhado em campo.

2. Para diferenciar a comunidade ou aldeia da associação indígena, usarei, no primeiro caso, a grafia em minúsculas e, no segundo, em maiúsculas.

3. Para um apanhado da complexidade dessas classificações e autodenominações entre os Arawak subandinos, que ainda geram muitas polêmicas entre linguistas, antropólogos, mas também entre os próprios índios, ver Santos e Barclay (2005: XIX-XXIII).

4. A região da Selva Central é pouco precisa, mas tem sido usada para designar a região amazônica situada na área central a leste da cordilheira andina peruana. O território Ashaninka situa-se entre os paralelos 10 e 14 (latitude sul) e os meridianos 72 e 76 (oeste) e tem uma extensão total de cerca de cem mil quilômetros quadrados (Varese, 1973: 39).

5. No Alto Juruá, os Ashaninka estão presentes na TI Jaminauá/Envira (80.618 ha), TI Riozinho do Alto Envira (260.970 ha), TI Kampa do Igarapé Primavera (21.987 ha), TI Kampa do Rio Amônia (87.205 ha), TI Kampa e Isolados do Rio Envira (232.795 ha), TI Kaxinawá-Ashaninka do Rio Breu (31.277 ha) e TI Kaxinawá do Rio Humaita (127. 383 ha). Com exceção da Terra Indígena Kampa do Rio Amônia e da TI Kampa do Igarapé Primavera que registra uma população de somente 26 pessoas, em todas as outras terras indígenas, eles dividem o território com um ou mais povos indígenas. Apesar de tentativas de lideranças da Apiwtxa de envolver outras comunidades ashaninka do Brasil, principalmente do rio Breu, em suas ações, a atuação dos outros ashaninka do Brasil na política interétnica é extremamente discreta. Eles não participam das alianças transfronteiriças, o que não significa que não existam relações sociais tanto com os Ashaninka do Rio Amônia, como com comunidades do Peru.

6. A rejeição a esse termo parece, de fato, muito mais intensa no Peru que no Brasil. Os Ashaninka do Rio Amônia se esforçam para que os brancos regionais deixem de usar o termo Kampa e passem a utilizar Ashaninka, mas nunca presenciei cenas onde eles se mostrassem particularmente irritados por serem chamados de "Kampa". Já no Peru, o uso desse termo é considerado um insulto. Ver, também, Shäfer (1982).

7. Na aldeia Apiwtxa, todas as mulheres ashaninkas vestem a kitharentsi. No caso dos homens, seu uso é menos sistemático, já que a vestimenta não é utilizada em atividades como as caçadas, pescarias, trabalhos penosos no roçado, partidas de futebol, etc. No entanto, todos os homens e meninos ashaninkas têm sua kushma e a vestem cotidianamente.

8. O Peru tornou-se um dos principais exportadores de madeiras tropicais. Em 2012, um relatório do Banco Mundial estimou que $80 \%$ da madeira peruana era extraída ilegalmente (Gonçalves, 
2012). A exploração de madeira no Peru também é associada à lavagem de dinheiro do narcotráfico e ao trabalho escravo (Garland e Silva-Santisteban, 2005).

9. O mais conhecido desses conflitos ocorreu em junho de 2009, em Bagua, quando indígenas de várias etnias protestaram contra dois decretos legislativos que facilitavam a exploração dos recursos naturais amazônicos, atendendo a interesses econômicos sem consulta aos povos indígenas. Amplamente noticiado pela mídia internacional, o conflito de Bagua fez 33 mortos entre manifestantes indígenas e policiais e deixou mais de 200 feridos. Tornou-se símbolo da resistência indígena às políticas desenvolvimentistas do governo peruano para a região amazônica. Sobre o conflito, ver, por exemplo, Peñafiel e Radomsky (2011). Para uma apresentação dos projetos do governo peruano para a Amazônia, ver Dourojeanni, Barandiarán e Dourojeanni (2009).

10. A Comunidad Nativa Sawawo - Hito 40 conta hoje com uma população de cerca de 130 pessoas e fez uma demanda de ampliação do seu território para que ele se torne fronteiriço à Comunidad Nativa Alto Tamaya - Saweto, da qual falarei adiante. Sawawo está ligada por uma trilha florestal, percorrida em cerca de oito horas de caminhada, ao pequeno município peruano de Puerto Breu, situado no rio Juruá, na fronteira com o Brasil.

11. Nessas operações, muitas delas incentivadas e acompanhadas pelos índios de Apiwtxa, dezenas de madeireiros peruanos foram presos, ramais e acampamentos clandestinos destruídos e milhares de metros cúbicos de madeira apreendidos. As missões de fiscalização também desativaram laboratórios clandestinos de pasta base de cocaína, instalados por narcotraficantes em território brasileiro, no Parque Nacional da Serra do Divisor.

12. No recorte administrativo do Estado peruano, a Comunidad Nativa Alto Tamaya -Saweto não é parte do distrito do Yuruá. Ela se localiza nas cabeceiras do rio Tamaya, no distrito de Masisea, província de Coronel Portillo, região do Ucayali. Sobre a história e a luta dos Asheninka de Saweto, ver, também, o artigo de Osório neste dossiê.

13. Junto com seus companheiros, Edwin Chota também participava do "Grupo de Trabalho para a Proteção Transfronteiriça do Alto Juruá e da Serra do Divisor - Brasil/Peru”. Criado em Cruzeiro do Sul, em abril de 2005, no contexto das invasões madeireiras da Forestal Venao à Terra Indígena Kampa do Rio Amônia e ao Parque Nacional da Serra do Divisor, este grupo binacional reúne organizações da sociedade civil e dos movimentos sociais da região de fronteira: ambientalistas, indigenistas, seringueiros, povos indígenas etc. De modo geral, monitora os projetos de desenvolvimento e procura interferir no planejamento das políticas públicas, propondo diretrizes para um plano binacional de proteção da biodiversidade, dos povos indígenas e das "populações tradicionais" dessa fronteira internacional. Os Ashaninka e a CPI-Acre foram os principais protagonistas na sua criação.

14. Existem trilhas que ligam o município de Marechal Thaumaturgo à região peruana do alto rio Putaya, cortando o Parque Nacional da Serra do Divisor. Brasileiros e peruanos são acusados de atuar nessa região, tanto no corte ilegal de madeira, como na produção de pasta base de cocaína.

15. Durante o nosso encontro em Pucallpa, em fevereiro de 2017, Diana Rios se queixou do total abandono no qual se encontrava a sua comunidade, hoje com cerca de 150 pessoas. Fez uma longa lista de demandas: educação, saúde, incentivo à produção, etc. Também relatou que os Ashaninka de Saweto vivem numa situação de medo permanente, já que madeireiros e homens armados ligados ao narcotráfico continuam atuando na região. 
16. Um exemplo dessas articulações transfronteiriças interétnicas foi o já mencionado "Grupo de Trabalho para a Proteção Transfronteiriça do Alto Juruá e da Serra do Divisor - Brasil/Peru”. Nos últimos dez anos, os Ashaninka do Rio Amônia participaram de vários encontros transfronteiriços e multiplicaram os contatos com associações indígenas peruanas da faixa de fronteira e da região do Ucayali. É o caso, por exemplo, com a Associação das Comunidades Nativas para o Desenvolvimento IntegralYono Sharakoiay (ACONADIYSH), cuja sede está no pequeno município de Puerto Breu e reúne seis povos indígenas da região do rioYuruá. Também mantem contatos regulares com a Associação Regional Aidesep do Ucayali (ORAU), da qual falarei adiante. A APIWTXA e a prefeitura de Marechal Thaumaturgo, administrada pela liderança ashaninka Isaac Pinhanta, também têm procurado aproximações com o município peruano de Puerto Breu, situado no rio Juruá, na divisa com o Brasil.

17. O "Projeto Alto Juruá" foi o primeiro projeto concebido e apresentado diretamente ao Fundo Amazônia por uma comunidade indígena, sem intermediação do setor público ou de ONGs. Com duração de três anos, prevê ações em três áreas principais, sendo duas terras indígenas (Terra Indígena Kampa do Rio Amônia e Terra Indígena Kaxinawá/ Ashaninka do Rio Breu) e uma unidade de conservação de uso sustentável (Reserva Extrativistas do Alto Juruá). Abrange um território de 624.668 hectares, correspondente a 80\% do município de Marechal Thaumaturgo e beneficia uma população de cerca de oito mil pessoas, formada por indígenas e extrativistas. Seu objetivo geral é promover o manejo e a produção agroflorestal nessas comunidades como alternativa econômica sustentável ao desmatamento, além de apoiar iniciativas de monitoramento e controle do território e fortalecer as organizações comunitárias.

18. As ações preveem apoio ao intercâmbio entre lideranças Ashaninka dos dois lados da fronteira para troca de experiências, discussões sobre monitoramento dos territórios, busca de alternativas econômicas sustentáveis, etc.

19. Fundada em 1980, a Associação Interétnica de Desenvolvimento da Selva Peruana (AIDESEP) é a principal associação indígena da Amazônia peruana. Agrupa 64 povos, conta com nove organizações indígenas regionais decentralizadas, 109 federações e representa mais de 1800 comunidades indígenas (http:/ / www.aidesep.org.pe/quienes-somos/). A ORAU é a representante regional da AIDESEP no Ucayali. Segundo Lizardo Cauper Pezo, liderança Shipibo e então seu presidente, entrevistado em fevereiro de 2017 em Pucallpa, a ORAU foi fundada em 1999 e representa quinze povos indígenas localizados em três departamentos: Loreto, Ucayali e Huánuco. No total, são 315 comunidades, quase metade delas Ashaninka.

20. Estou ciente de que as condições do meu trabalho de campo no Peru podem ter influenciado nessa idealização da APIWTXA por meus interlocutores, já que na maior parte dos encontros, eu estava acompanhado por uma liderança ashaninka do Rio Amônia.

21. Essa questão não é relevante no caso de APIWTXA, que sempre manteve sua agenda política de modo independente do movimento indígena regional ou nacional, o que não os impede de demonstrar uma solidariedade pan-indígena, participar de manifestações comuns ou ainda de intercâmbios com outros povos indígenas do Brasil.

22. Essa situação mudou recentemente. Em dezembro de 2017, Lizardo Cauper Pezo, indígena shipibo, tornou-se presidente da AIDESEP e o ashaninka Reider Sebastian Quinticuari, antigo Presidente da ACONAMAC, foi eleito Presidente da ORAU para a gestão de 2018 a 2020. 


\section{Referências bibliográficas}

ALVAREZ, Ricardo, 1981. “Unión panselvatica”. Antisuyo, 5: 5-39.

BARTH, Fredrik (org.). 1969. Ethnic Groups and Boundaries. The Social Organization of Culture Differences. Boston: Little Brown \&Co.

BARTOLOMÉ, Miguel. 1998. "Procesos civilizatorios, pluralismo cultural y autonomías étnicas en América Latina. In. Miguel Bartolomé e Alicia Barabas (org.). Automomías étnicas y Estados nacionales. México, DF: Conaculta / Instituto Nacional de Antropología e História, pp. 171-194. BRYSK, Alison. 2000. From Tribal Village to Global Village. Indian Rights and Internacional Relacions in Latin America. Stanford: Stanford University Press.

CARDOSO DE OLIVEIRA, Roberto. 2006. "Os (des)caminhos da identidade (etnicidade e multiculturalismo)”. In: Roberto Cardoso de Oliveira (ed.). Caminhos da identidade: ensaios sobre etnicidade e multiculturalismo. São Paulo, Brasília: Editora Unesp, Paralelo 15, pp. 97-115.

CARNEIRO, Eduardo de Araújo. 2014. A invenção do Acre: um estudo sobre comemorações cívicas e "abusos da história”. Tese de Doutorado, Universidade de São Paulo.

COSTA, Craveiro. 1998 [1973]. A conquista do deserto ocidental. Subsídios para a história do território do Acre. Rio Branco: Fundação Cultural do Estado do Acre.

DOUROJEANNI, Marc; BARANDIARÁN, Alberto e DOUROJEANNI, Diego. 2009. Amazonía peruana en 2021. Lima: ProNaturaleza - Fundación Peruana para la Conservación de la Naturaleza. EVANS-PRITCHARD, Edward. 1978. Os Nuers. São Paulo: Perspectiva.

GARLAND, Eduardo Beloya; SILVA-SANTISTEBAN, Alvaro Bedoya. 2005. El trabajo forzoso en la extraccion de la madera en la Amazonia peruana. Genebra: OIT

GAVAZZI, Renato Antonio (org.). 2012. Etnomapeamento da terra indígena Kampa do Rio Amônia: o mundo visto de cima. Rio Branco: G. K. Noronha.

GONÇALVES, Maryline Perreira (org.). 2012. Justice for Forest: improving criminal justice efforts to combat illegal logging. Washington: World Bank Series.

HILL, Jonathan e SANTOS-GRANERO, Fernando. (org.). 2002. Comparative Arawakan histories: rethinking language family and culture area in Amazonia. Urbana-Champaign: University of Illinois.

HVALKOF, Søren e VEBER, Hanne. 2005. “Los Ashéninka del Gran Pajonal”. In: Fernando Santos Granero e Frederica Barclay (org.). Guía Etnográfica de la Alta Amazonía, volume V, Campa Ribereños, Ashéninka. Lima: Instituto Smithsonian de Investigaciones Tropicales / Instituto Francês de Estudios Andinos. pp. 75-279.

LATHRAP, Donald. 1970. The Upper Amazon. London: Tames \& Hudson.

MENDONÇA, Belarmino. 1989 [1906]. Reconhecimento do rio Juruá (1905). Belo Horizonte, Rio Branco: Editora Itatiaia, Fundação Cultural do Estado do Acre

PEÑAFIEL, Adriana Paola Paredes e RADOMSKY, Guilherme. 2011. "Dilemas da intercularidade e da biodemocracia: o massacre em Bagua, Amazônia peruana.” Amazônica, 3 (1): 60-87.

PERRISSER, Jean-Baptiste. [1898] 2009. "Seis meses no país da borracha, ou excursão apostólica ao rio Juruá, 1898”. In: Manuela Carneiro da Cunha (org.). Tastevin, Perrissier. Fontes sobre índios e seringueiros no Alto Juruá. Rio de Janeiro: Museu do Índio - FUNAI,pp. 1-60. 
PIMENTA, José. 2015. "O amazonismo acriano e os povos indígenas: revisitando a história do Acre”. Amazônica: Revista de Antropologia, 7 (2): 327-353.

2012a "Parentes diferentes: etnicidade e nacionalidade entre os Ashaninka na fronteira Brasil-Peru. Anuário Antropológico 2011/I: 91-119.

2012b. "Povos indígenas, desenvolvimento e integração fronteiriça: o caso do Acre e da fronteira Brasil-Peru”. In: José Pimenta e Maria Inês Smiljanic (org.). Etnologia indígena e Indigenismo. Brasília: Positiva: Brasília, pp. 75-99.

2010. "O caminho da sustentabilidade entre os Ashaninka do Rio Amônia”. In: Cássio Noronha Inglêz de Souza, Fábio Vaz Ribeiro de Almeida, Antonio Carlos de Souza Lima, Maria Helena Ortolan Matos (orgs.). Povos indígenas: projetos e desenvolvimento II, Rio de Janeiro: Paralelo 15, pp. 97-111.

RAMOS, Alcida Rita. 1996. "Nações dentro da nação: um desencontro de ideologias”. In: George Zarur (org.). Etnia e Nação na América Latina. Washington: OEA, pp. 79-87.

RENARD-CASEVITZ, France-Marie. 1992. "História Kampa, Memória Ashaninka”. In. Manuela Carneiro da Cunha (org.). História dos índios no Brasil. São Paulo: Núcleo de História Indígena e do Indigenismo/Fundação de Amparo a Pesquisa do Estado de São Paulo/Companhia das Letras, pp. 197-212.

SANTOS, Fernando; BARCLAY, Frederica. 2005. “Introducción”. In: Fernando Santos e Frederica Barclay (orgs.). Guía Etnográfica de la Alta Amazonía - Volume V - Campa Ribereños, Ashéninka. Smithsonian Tropical Research Institute/Instituto Smithsonian de Investigaciones Tropicales, pp. XV-XLI.

SCHÄFER, Manfred. 1982. "Yo no soy Campa, soy Ashaninka!”. Amazónia Indígena, 4: 30-31. TOCANTINS, Leandro. 1979. Formação Histórica do Acre. Rio de Janeiro: Civilização Brasileira. VARESE, Stefano. 1973. La sal de los cerros. Lima: Retablo de Papel. 
Resumo: Este artigo discute as alianças intraétnicas transfronteiriças entre os Ashaninka do Rio Amônia do Alto Juruá brasileiro e os Ashaninka do Peru, principalmente da região do Ucayali. Apresenta o contexto histórico que levou à demarcação dos limites internacionais entre Brasil e Peru na região do Alto Juruá e discute os diversos significados da fronteira para os Ashaninka do Rio Amônia. Mostra que as alianças transfronteiriças recentes que procuram reunir esse povo indígena para além da fronteira dos Estados-nações são, sobretudo, uma resposta aos projetos governamentais de desenvolvimento e integração binacional e às atividades ilegais em curso na região. Embora se considerem um povo único, as alianças intraétnicas binacionais ashaninkas não revelam qualquer aspiração à independência como Estado, nem negam as identidades nacionais. Elas devem ser vistas, sobretudo, como uma estratégia política na defesa de seus territórios e de seus direitos diante das ameaças externas.

Palavras-chave: Ashaninka, fronteira Brasil-Peru, alianças intraétnicas, etnopolítica, Estado
Abstract: This article discusses the trans-frontier, intra-ethnic alliances between the Ashaninka of the Amonia River on the Upper Juruá in Brazil and the Peruvian Ashaninka, especially of the Ucayalli region. It describes the historical context that led to the demarcation of the international border between Brazil and Peru on the Upper Juruá. It discusses the various meanings of frontier for the Amonia Ashaninka, and shows how recent trans-frontier alliances aim at reuniting this indigenous people beyond the international border. They are mostly a reaction to governmental projects of development and binational integration and to the illegal activities underway in the region. Although the Ashaninka see themselves as one people, their binational intra-ethnic alliances reveal no aspiration whatsoever to independence as a State, nor do they deny their national identities. These alliances should be regarded mainly as a political strategy to defend their territories and their rights against external threats.

Keywords: Ashaninka, Brazil-Peru border, intra-ethnic alliances, ethnopolitics, State 